\title{
What is Postwar Multiculturalism in Theory and Practice?
}

\author{
Richard T. Ashcroft, University of California, Berkeley \\ Mark Bevir, University of California, Berkeley
}

Cultural diversity raises pressing issues for both political theory and practice. The remaking of the world since 1945 has increased demographic diversity within many states, and led to greater acknowledgment of the value of social heterogeneity. The heightened awareness of difference has contributed to pressure on traditional forms of liberal-democratic governance, which historically have operated within polities that are-or at least have assumed themselves to be-broadly culturally homogeneous. The term "multiculturalism" refers to the political, legal and philosophical strategies that emerged after World War II to accommodate this newfound social diversity. For much of this period, multiculturalism enjoyed a steady rise to prominence, but in recent years the growing consensus has been questioned by politicians and prominent social commentators. Whether this amounts to a "retreat" or "rebalancing" is still being debated, but it is clear that multiculturalism is being reevaluated. This volume adds to the existing empirical and normative literature by situating modern multiculturalism in its national, international, and historical contexts, bringing together practitioners from across the humanities and social sciences. It addresses questions vital for understanding contemporary debates: What is "multiculturalism," and why did it come about? What dilemmas has it posed for liberal-democratic governance? How have these been responded to in theory and practice, and are the different responses adequate? Are there alternative approaches to cultural diversity that have been overlooked?

We start this introductory chapter by sketching the different issues that may be characterized as "multicultural," noting how the scope of the term varies between different contexts and straddles theory and practice. We nevertheless provide a rough definition to help guide our analysis, and situate modern multiculturalism 
historically. We trace the connection between contemporary debates and the period of decolonization and globalization following World War II, which itself has its roots in the interrelated rise of nation, state, and empire in the early modern period. We demonstrate that the Commonwealth is a crucial context for studying multiculturalism, gathering together the key philosophical and empirical issues. We then show how this volume contributes to the literature by facilitating fruitful comparison across national, historical, and disciplinary boundaries. Finally, we set out the structure of the volume, and summarize the chapters that follow.

\section{WHAT IS MULTICULTURALISM?}

To call a society "multicultural" is to claim that it contains multiple cultural groups rather than just one. In the abstract, therefore, "multiculturalism" is simply the opposite of cultural homogeneity. In concrete terms, however, "multiculturalism" evokes a series of discourses regarding the appropriate way to respond to cultural and other forms of difference. These debates cover a wide variety of topics, including appropriate modes of dress, land rights, anti-racism, religious freedom, court procedure, immigration, language and educational policy, the scope of human rights, and even the basic structure and aims of the polis. The study of multiculturalism thus provides a meeting point for a variety of scholarly disciplines, including social science, law, history, anthropology, philosophy, and public policy. Discussion of multiculturalism is not limited to academia, however, but is also prominent in political and popular discourse.

In common use, the term "multiculturalism" can relate to a number of connected phenomena. For example, it may simply refer to the basic sociological fact of diversity, or alternatively to the challenges this diversity presents to our modes of thinking and governing. Sometimes it will directly invoke the policy or legal responses to these challenges, and some uses indicate normative approval of multicultural goals. Multiculturalism may be used as a catch-all term for the claims of marginalized groups, such as those who identify as LGBTQIA, people with disabilities, racial, ethnic and religious minorities, and women. A slightly different but overlapping usage refers to issues facing minority immigrants, and it is also frequently invoked in relation to minority national groups and indigenous peoples. Given the variegated nature of "multiculturalism," its meaning, application and value are inevitably contested, and subject to appropriation for different purposes in different contexts. This means we must guard against the temptation to reduce multiculturalism to a list of essential features that override its historicity.

Any simple definition of multiculturalism will therefore be potentially misleading, yet we must make some attempt to delineate the scope of our enquiry and enable comparison between the different cases. ${ }^{1}$ The different multicultural debates bear a family resemblance to one another, and so it is possible to identify certain recurring situations which may usefully be labeled "multiculturalism." 
For example, a common form of multiculturalism occurs where the practices of a previously dominant cultural group are challenged by the presence of a minority. Often members of the minority seek tolerance for behaviors that clash with majority norms, particularly if those norms have a disproportionate impact on their well-being. This may be accompanied by requests for exemptions from relevant legal provisions (e.g., regulations on animal slaughter), for reforms that facilitate the inclusion of the minority group (e.g., adapting rules on dress, language policies, or altering evidential procedure in courts), or for social policies aimed at promoting intra-societal understanding and inclusion (e.g., educational policy, reforming public symbols/holidays, or funding community activities).

Multiculturalism is not limited, however, to issues stemming from the interaction of minority and majority norms. It frequently engages broader issues in governance. For example, sometimes a minority will demand control of a practice, institution, or resource, such as the ability to conduct legal marriages, a separate religious court, or rights over land or language. Multiculturalism is thus also implicated in debates regarding fundamental aspects of the polis, including constitutional structures, national identity, immigration restrictions, basic rights, and forms of special political representation or self-rule. These questions can occur when there is no clear majority, but rather multiple groups co-exist within a polity. The precise scope of the term "multiculturalism" therefore varies across the different countries of the Commonwealth, but always involves the basic problem of how to manage deep-seated diversity, and consideration of the implications of this diversity for governance. Multiculturalism thus consistently challenges the validity of basic norms, and calls into question the political, economic and cultural processes through which they are expressed. Multiculturalism thereby inevitably poses societal dilemmas at the level of both theory and practice.

\section{THEORY AND PRACTICE}

There are several different senses of "theory" and "practice" relevant to this volume, the most salient of which relate to the understandings of multiculturalism in politics and academia. ${ }^{2}$ In political practice, multiculturalism is largely construed in relation to postwar immigration. The central debate in this conceptualization is regarding the merits of assimilation versus integration, and how best to achieve the desired outcomes through adjustments in policy and law. This understanding of multiculturalism predominates worldwide in current political discourse and has been the subject of much recent public debate. Multiculturalism in academia is closely associated with political theory, where its scope is much broader than in political debates. In that literature, which is dominated by thinkers from Canada, Australia, and New Zealand, multiculturalism encompasses, not just immigrant integration, but also groups such as the Québécois and indigenous peoples and their claims for political autonomy or reparations. 
Most uses of the term "multiculturalism" will draw on these understandings of its theory and practice, which continue to condition political and academic discourse even as they are subject to challenge. Yet there are other forms of theory and practice relevant to multiculturalism. For example, cultural diversity calls into question both standard methods of liberal-democratic governance, and the fundamental principles underlying them. Justifications of both liberalism and mass democracy are typically cast in terms of a moral universalism that presumes similarly situated individuals should be treated the same regardless of, inter alia, religion, race, sex, gender, culture, and sexual orientation. This traditional "difference-blind" approach has been called into question by multiculturalism, as have prominent formulations of doctrines such as political equality, state neutrality, and the rule of law. Increased cultural diversity highlights cleavages within liberal democracy masked by greater homogeneity, including those between individual rights and majority rule, positive and negative liberty, and between nation and state. These potentially destabilizing effects have been compounded by postwar immigration that threatened dearly held aspects of collective identities, including forms of national identity that many argue are necessary for liberal-democratic practice. ${ }^{3}$ Multiculturalism therefore poses particularly acute problems for liberal democracies, highlighting tensions that straddle political philosophy and practice, between, for example, sameness and difference, public and private, local and central, individual and community, and particular and universal.

Furthermore, questions of theory and practice are not easily separated from each other even analytically. In broad terms, theory relates to how we understand the world, and practice to how we respond to the world by acting. Yet understanding and action inevitably feed into each other, and are therefore mutually constructing. Their interrelationship is especially clear in the case of multiculturalism, where theory and practice cut across each other because cultural diversity poses both pressing social questions and complex philosophical puzzles. In fact, multicultural adaptations to liberal-democratic governance are themselves attempts to mediate normative claims derived from abstract principles and the historical specificity of particular groups/issues. The challenges multiculturalism presents therefore vary in relation to the different political institutions, national histories, intellectual traditions, and forms of diversity present in each case. These contexts themselves alter how liberal democracy itself is understood in each country, feeding back into the ways practical problems and philosophical questions are tackled.

We propose that the interrelated nature of theory and practice is not, however, just a empirical feature of multiculturalism in postwar liberal democracies, but rather should be a basic philosophical presumption that informs how we approach its study. The editors share an underlying commitment to holism, which we have defended at length elsewhere. ${ }^{4}$ Holism is grounded in the idea that we cannot approach facts or propositions in an isolated, atomistic way, as is typical in analytic philosophy or positivist social science. This means there are 
no entirely tautologous statements, pure facts, or self-evident truths, and so none of them can serve as unassailable foundations for our beliefs. Holism shows that our theories and observations-moral, political, and empirical-form an intertwined and mutually constructing set. Within these "webs of belief," our theories condition our observations and our experiences challenge our theories, which means there can be no points that are absolutely immune from revision. Instead, all knowledge arises within the contingent world view of particular individuals, who are in turn embedded in a nexus of traditions and practices constituted by the beliefs and actions of others. Abstract argument and empirical investigation are thus open-ended, and are undertaken by historically situated individuals against a background of overlapping influences. Holism therefore pushes us toward interpretivist forms of the human sciences and away from the logical positivism that still dominates modern social science research and government policy-making. ${ }^{5}$ We should therefore privilege description and explanation, rather than prediction, and prefer certain types of empirical evidence over others. For example, holism indicates we should be wary of formal models that treat their data as atomized units of information to be processed, and focus instead on constructing continuous and coherent narratives. As holism commits us to the basic presumption that theory and practice constantly remake each other, it also implies that historical investigation and philosophical analysis are not separate activities, but rather must go hand in hand, and may productively inform each other. ${ }^{6}$

Proponents and critics of multiculturalism have, however, a common tendency to rely on unsubstantiated claims regarding the empirical consequences of multiculturalism, including the effects of multicultural political theory and political practice on each other.7 Given the tangle of theoretical and practical issues raised by multiculturalism, it is unsurprising that the academic literature-in particular political theory-has fed into political and legal approaches to both immigrants and national minorities, and that theoretical understandings of multiculturalism have evolved in the light of political/legal practice as well as philosophical concerns. ${ }^{8}$ Yet, while holism indicates that theory and practice are mutually constructing, it also suggests that this is a dynamic process that will take place in myriad different ways, constantly reshaping the beliefs and actions of particular actors. We must therefore be cautious of broad-brush claims regarding the precise effects of multicultural theory and practice, even as we acknowledge these effects must exist. Detailed historical study, including examining the relevant intellectual traditions and arguments, will be needed to recover these effects, and even then clear causation may be hard to establish. Any conclusions we draw regarding the theory and practice of multiculturalism are necessarily generalizations from concrete historical examples and must be applied with a suitable degree of caution.

Ultimately, therefore, holism foregrounds the importance of an integrated approach to studying multiculturalism. Particular beliefs, theories, or practices are neither plucked from the ether by pure reason nor revealed to consciousness by 
unmediated experience. They are only intelligible within an appropriately defined context, which must not only delineate the relevant concepts and modes of reasoning but should also foreground the dilemmas that have spurred a reevaluationand potential reconstitution-of a set of beliefs and, through them, the broader theories and practices in which those beliefs are embedded. In order to understand multiculturalism in both its philosophical and empirical aspects, we must therefore situate it within its relevant historical, national, and intellectual contexts.

\section{SITUATING POSTWAR MULTICULTURALISM}

Although cultures have come into contact with each other throughout history, the problem of how to manage these interactions between and within states became especially prominent after $1945 .{ }^{9}$ The parallel processes of decolonization and globalization set in motion the movement of both people and ideas on a vast scale, creating in many societies a substantive rise in cultural diversity and increased awareness of it. The related rise of human rights discourse, identity politics, and indigenous movements led to greater acknowledgement of the plight of minority groups, which in many societies prompted policies self-consciously addressing the challenges of cultural diversity. These policies started in the immediate aftermath of World War II, but became more prominent in the 1970s, when both Canada and Australia adopted official state multiculturalism. Many other liberal democracies adopted similar policy approaches in the following decades, with most public actors consistently endorsing multiculturalism in some form. The steady rise of multiculturalism was halted by the events of 9/11, which, as well as raising the specter of domestic terrorism, triggered the "war on terror" and the invasions of Afghanistan and Iraq. This has led some commentators to argue that multiculturalism is experiencing some form of crisis, adding fresh urgency to already volatile debates. ${ }^{10}$

Modern multiculturalism as a set of social realities and related series of discourses must therefore be situated primarily in the period from 1945 to the present day, which is the main focus of this volume. Its factual and philosophical roots go back much deeper, however, to the gradual, haphazard and contested rise of the nation and state as the dominant forms of social organization in the West. In the early modern period, the shift from smaller feudal and sacral communities to larger modern society gave rise to new forms of governance with which to manage the inevitable social upheaval. ${ }^{11}$ As the modern liberal and bureaucratic state developed, it impinged on earlier forms of social organization, which inevitably provoked resistance, fueling conflict between the central and local. These tensions were exacerbated by the Reformation and the rapid socioeconomic changes driven by capitalism, with the rise of nationalism partly attributable to the dislocating effects of these. The modern nation-state thus evolved partly in order to manage greater social diversity, yet simultaneously facilitated forms of social and political cohesion operable on a far larger scale than in previous eras. 
These developments coincided with the heyday of European imperialism, and both domestic and international policy during the nineteenth century were primarily narrated through developmental histories that valorized Enlightenment liberalism and rationalism. ${ }^{12}$ Simple progressivist narratives became unsustainable in the twentieth century, however, when two world wars and a growing awareness of the realities of imperialism undercut assumptions regarding the superiority of the West. The postwar unraveling of imperialism therefore set the stage for contemporary multiculturalism by foregrounding hollow aspects of the West's self-understanding and causing a huge increase in its demographic diversity. Decolonization thus posed problems for liberalism and democracy at the level of both theory and practice, contributing directly to the series of postwar civic resettlements in both Europe and her former colonies. These reconstitutions of the state-and the self-understandings of the nation often conflated with it-resulted in the series of social dilemmas we refer to as "multiculturalism."

The British Commonwealth spans multiculturalism's relevant national, international, and historical contexts and therefore is vital for its study. The central sites of liberal-democratic governance are nations and states, which are both the fora within which the social world is remade and communities subject to that remaking. This means multiculturalism should be narrated in relation to national context, and the Commonwealth provides a rich array of cases to draw on. Given the direct connection of multiculturalism to imperialism, however, it cannot be understood purely as a domestic phenomenon. The intra- and international elements of multiculturalism are ineradicable, and thoughtful analysis requires an awareness of both. The Commonwealth foregrounds this dualism, forming a common context within which states have negotiated multiculturalism, and bringing about demographic, political, and cultural (including philosophical) connections between member countries. These connections have been forged primarily through Britain's imperial influence, but also through the "Old" Commonwealth's genesis of influential approaches to multiculturalism, and the "New" Commonwealth's role as a significant source of migrants to other member states. ${ }^{13}$ The consistent movement of people, goods and ideas within the British Empire and Commonwealth has thus produced a degree of commonality across the member states, which aids our analysis. Utilizing it as a framework enables us to trace the different trajectories of multiculturalism, but also to find connected vantage points from which to compare these. For example, the Commonwealth provides a perspective from which to view both the nation-states and the crossnational movement central to multiculturalism. It also facilitates comparison across time and geographic locale, bridging the relevant short-, medium-, and long-term contexts. The Commonwealth and multiculturalism have grown alongside each other in the postwar period, and share roots in the earlier practices of imperialism and nation-state building that shaped modern liberal democracy. The rise and fall of empire is central to multiculturalism on both empirical and 
normative levels, which makes the Commonwealth a particularly useful framework for its study.

By cutting across disciplinary, temporal and geographical borders in one volume, Multiculturalism in the British Commonwealth: Comparative Perspectives on Theory and Practice highlights which aspects of multiculturalism are ubiquitous, and which are specific to particular localities. This volume thereby facilitates methodologically sound, intellectually fruitful comparison of the theory and practice of multiculturalism, enhancing previous scholarship. The literature is as variegated as multiculturalism itself, and so it is difficult to encapsulate it neatly or to identify clear gaps. Nevertheless, we can determine three main strands that this volume speaks to and enriches: political theory, specific case studies, and comparative work.

In the academy, multiculturalism is most closely associated with political theory, and has multiple strands which can be characterized in a variety of ways depending on one's purposes. ${ }^{14}$ Nevertheless, it is possible to identify some features broadly accepted by advocates and opponents of multiculturalism alike. Most obviously, the agenda for the literature been shaped by the early work of the Canadian philosopher Will Kymlicka, which set out a liberal defense of multicultural rights grounded in the importance of culture for autonomous choice and self-respect. ${ }^{15}$ The core debates revolve around the ability of liberalism to respond suitably to minority groups in both theory and practice, with Kymlicka's theory usually taken as the starting point ${ }^{16}$ The literature has been dominated by thinkers from the Old Commonwealth-especially Canada-which has likely contributed to a focus on concerns prominent in those countries. The political theory of multiculturalism is thus centered around appropriate policy approaches to, and the legal rights of, immigrant groups, minority nations such as the Québécois, and indigenous peoples. Most multicultural theorists utilize these categories of groupsalbeit with varying levels of endorsement and rigidity-with the majority seeing them as entitled to different bundles of multicultural rights. Immigrant groups are usually only allocated "polyethnic" rights aimed at integrating them into the host society, whereas "national minorities" such the Québécois and indigenous groups are frequently seen as entitled to some form of political autonomy, with some theorists arguing that the latter also have a right to historical reparations. ${ }^{17}$ There is therefore an overall tendency to separate groups and rights typologically, largely on the basis of the varying historical experiences of the relevant minorities and/or the putatively different role culture plays for the members of each. Whereas early multicultural theory tended to employ the universalist style of reasoning prevalent in post-Rawlsian liberal philosophy, subsequently there has been a shift toward more context-sensitive and politically oriented forms of theorizing. ${ }^{18}$ This has led to qualification of the more robust normative claims associated with early philosophical multiculturalism, and a recent focus in Anglophone political theory on particular cases in their immediate historical circumstances. Nevertheless, 
most political theorists still utilize some form of the basic organizing typology of groups and rights drawn from the Old Commonwealth, and therefore the focus on immigrant groups and national minorities remains, as does the clear tendency of advocates of multiculturalism to limit claims to self-government to the latter. ${ }^{19}$

This volume makes an important contribution to the political theory literature in two main ways. Firstly, it highlights that the standard typology is tailored to historically specific situations and may have limited traction in contexts where not all of the groups are present. Also, by tracing the connections between the different forms of postwar multiculturalism, it demonstrates that even where all these groups are present, their precise interactions are conditioned by local factors, particularly their varying experiences of colonialism. In turn, this foregrounds problematic presumptions behind the ascription of different rights to different groups, particularly those grounded in functional accounts of the relationship between culture and liberal-democratic governance. For example, many prominent political theorists assume that "the nation" or "culture" plays a central-perhaps even necessary-role in governance. ${ }^{20}$ Advocates of multicultural rights therefore tend to take for granted that there is a stable cultural "core" to the typical nation-state, which must be adjusted in response to minority claims, and critics often oppose multicultural rights on the grounds that they will erode common principles and values central to liberal democracy. Yet we will see that these sorts of assumptions have limited application in the New Commonwealth, and that the historical cases show the relationships between culture, nation, state, and governance to be both highly contingent and deeply conditioned by empire. This volume therefore complicates the typology of groups and rights that frames multiculturalism in political theory, foregrounding problematic assumptions behind it and forcing us to rethink central normative claims.

Secondly, this volume helps to mitigate a broader tension between universalist and contextualist approaches that poses risks for the study of multiculturalism. For example, abstract normative argument without an understanding of historical context falsely homogenizes real-world difference, yet methodological contextualism in turn has difficulty avoiding a relativism that loses normative purchase altogether. This volume considers multiculturalism without committing a priori to universalism or contextualism, and is therefore able to speak productively to both. Our case-by-case exploration of multiculturalism in its various historical, geographical, and temporal contexts militates against the homogenizing tendencies of universalist theory, but the overall volume highlights commonalities between the normative issues at play in different countries. It therefore provides material useful to both universalists and contextualists, while challenging extreme versions of either approach.

Another aspect of the multicultural literature is comprised of detailed investigations of individual countries, or specific cases within those countries. ${ }^{21}$ This strand overlaps with some of the narrower contextualist case studies in political 
theory, but differs in that its primary focus is descriptive rather than normative. These case studies therefore tend to possess greater historical detail and depth than even the more empirically minded forms of political theory. Yet in doing so, they can lose sight of the international aspects of modern multiculturalism, or only assess these from a particular domestic perspective. This reduces the possibility of fruitful comparison across national contexts, and an empirical focus can mean that scant attention is paid to normative issues, which are inseparable from multiculturalism in both theory and practice. Even if descriptive accounts of the normative issues are provided, the lack of mechanisms for comparison and assessment make this literature less likely to address the core normative questions, or to do so in a context-specific way. Case studies thus run the risk of joining more radical contextualist political theory in focusing so tightly on particular circumstances that critical perspective is compromised.

As well as providing a series of detailed and insightful case studies of multiculturalism, the volume as a whole adds to the literature by retaining considerable historical depth without foregoing normative purchase. Using the Commonwealth to frame the array of cases covered in the different chapters ensures we do not lose sight of the fact that the different national contexts are connected by historical, international, and philosophical exchanges, which also influence the form multiculturalism takes within them. It ensures that the fundamental empirical and theoretical connections between multiculturalism, decolonization, and liberal-democratic governance are not hidden by the specific issues that occur in each country. This volume therefore facilitates comparison by highlighting the normative issues that reoccur across national contexts, while simultaneously throwing into relief their particular features.

The third aspect of the multiculturalism literature, and the one that this volume most obviously contributes to, is comparative in orientation. There are many excellent cross-national examinations of issues relevant to multiculturalism, embodying a vast array of methodologies, particular objects of study, and philosophical commitments. The comparative work on multiculturalism is therefore the most heterogeneous strand of the literature, and contains the greatest preponderance of self-consciously interdisciplinary work, making it difficult to summarize succinctly. ${ }^{22}$ Some works focus on comparisons between countries within particular geographical areas or organizations, or nations grouped together on the basis that they raise similar issues or provide useful contrasts. ${ }^{23}$ Other cross-national comparisons have focused on particular groups, such as indigenous peoples, or particular aspects of multicultural regimes, such as law, especially international or immigration law. ${ }^{24}$ Yet others focus either on the broad outline of contemporary national policy regimes and discourses or on much more specific aspects of multicultural policies, including their social effects. ${ }^{25}$

The existing comparative work on multiculturalism is, of course, extremely valuable, but we hope to supplement it. Multiculturalism in all its aspects is part 
of a process of contestation in which individuals and communities remake their social structures and understandings - and thereby their individual and collective identities - through complex patterns of discourse and praxis. Politics, economics, and culture therefore interact in different ways in each context, constructing idiosyncratic forms of multiculturalism. Utilizing the Commonwealth as a framework brings out the subtleties of each country's response to cultural diversity, mitigating the risk of circumscribing our understanding of multiculturalism ahead of time through selecting a narrower metric of comparison. Placing contemporary multiculturalism against its historical backdrop also illustrates the ways in which longterm factors feed into current debates. ${ }^{26}$ Examining the diverse historical sources of current legal and policy regimes mitigates the risk of reducing multiculturalism to current political and public understandings, thereby ignoring the thicker historical, cultural, and philosophical factors they draw on.

Overall, this volume speaks to and enriches all three main strands of the multicultural literature in ways that flow directly from our use of the Commonwealth as framework. Since the Commonwealth spans the relevant issues and time periods, we can approach multiculturalism in a holistic manner. Just as there is a family resemblance between the different issues that fall under "multiculturalism," there is also a family resemblance between the different countries in the Commonwealth that aids comparison across contexts and challenges assumptions prevalent in current debates. This volume will improve our understanding of any given national context, providing historical nuance that aids both comparison of contemporary policy debates and analysis of the normative issues, and we hope it will be a resource for scholars and students across various disciplines, sparking further scholarship.

\section{STRUCTURE AND CONTENT}

The volume is divided into three main sections, each dealing with a set of countries that raise distinctive but interrelated issues. The first section explores multiculturalism in the United Kingdom between 1945 and the present day. As the imperial metropole and subsequent head of the Commonwealth, Britain has been in a unique position to affect both the discourses and realties of multiculturalism, particularly in the immediate aftermath of World War II and the process of decolonization. This section will examine the political and legal trajectory of multiculturalism in the UK during this period, as well as analyzing historical and contemporary debates over Britishness and citizenship.

The second section looks at multiculturalism in the "Old" Commonwealth countries of Canada, Australia, and New Zealand. ${ }^{27}$ These historically whitedominated settler colonies have a history that is dissimilar from most other parts of the former empire, and as "Greater Britain" their political, legal, economic, and cultural relationships with the UK were also substantively different. All three of 
these countries have had comparable processes of settlement, contact with indigenous peoples, and immigration, and are generally considered to be world leaders in official approaches to cultural diversity in the postwar era.

The third part of the book contains chapters on the "New" Commonwealth countries of India, Nigeria, Malaysia/Singapore, and Trinidad and Tobago. These countries, although culturally and politically disparate, are all marked by histories of internal religious and ethnic diversity, and their experiences of both colonization and independence differ substantially from the Old Commonwealth. There are a number of commonalities and connections between them, which sharpens our understanding of multiculturalism, throwing into relief experiences elsewhere.

\section{PART I: BRITISH MULTICULTURALISM}

In chapter 2, the volume editors take a long-term view of multiculturalism in Britain, charting its political and legal trajectory from World War II to the present day. We argue that the radical changes undergone in Britain since 1945 must be traced back to the process of decolonization, which forced a reassessment of Britain's place in the world. A cross-party attempt to secure the Commonwealth as a distinct British sphere of influence led directly to legal reforms that sparked an unanticipated influx of nonwhite immigration. This resulted in an idiosyncratic "regime" of multiculturalism, comprised of tough external immigration controls and a generous internal regime of race-relations legislation, welfare rights, and pluralist accommodations for minority cultural groups. The bifurcated approach remained broadly stable from 1962 on, but there has been a strong rhetorical and weaker policy shift in recent years. Our narrative demonstrates that multiculturalism in Britain is closely associated with debates over immigration, race, citizenship, and national identity, and we argue that the interaction of these debates were a significant cause of the Brexit vote and renewed calls for Scottish independence. We conclude that the framing of multiculturalism in Britain as solely relating to immigrant integration is therefore inadequate, since it hides deeper connections between multiculturalism, basic constitutional issues, and a British national identity struggling to define itself after empire.

In chapter 3, Nasar Meer and Tariq Modood explore controversies over multiculturalism in contemporary Britain, arguing that recent political rejections of it have not been reflected in a wholesale change of policy, and that it is helpful to think of British multiculturalism as undergoing a rebalancing, rather than retreat. They argue that the fluid nature of British multiculturalism means that it can be co-opted by different actors for a variety of purposes. They identify three main strands in contemporary British multiculturalism: a "cohesion" strand that emphasizes assimilation to majority norms; a secular and anti-essentialist account that focuses on "lifestyle" and behavioral identities; and a "political" multiculturalism, prominent since the 1990s, that incorporates the priorities of both of the 
above but also stresses the inclusion of ethno-religious minority groups. It is this latter form of multiculturalism that has been subject to rhetorical criticism and policy rebalancing, but even here they find that British politicians of all stripes define "Britishness" through a simultaneous appeal to political-institutional history and cultural diversity.

\section{PART II: THE “OLD” COMMONWEALTH}

In chapter 4, Avigail Eisenberg examines the most prominent example of state multiculturalism in the world, that of Canada. She argues that multiculturalism in Canadian politics usually only refers to the issues surrounding the protection and integration of nonwhite immigrants and not the separate cases of Quebec and indigenous peoples. Despite the separation of these groups into different "silos," they still interact with each other through political and legal contests in ways that undercut the aims of Canadian multiculturalism. Firstly, the constitutional entrenchment of multiculturalism has politicized it by overriding the more local measures of the 1970s, which has prompted Quebec to allege anti-democratic overreach by the federal government. Secondly, multicultural policy is operationalized through a legal mechanism of "reasonable accommodation," which assumes that majority practices are a norm from which deviation must be justified. Thirdly, collective rights of groups have been subject to a "distinctive culture test" colored by the above, which renders legal remedies superficial and ignores deeper concerns over identity, recognition, and colonialism. Eisenberg concludes that the Canadian multicultural provisions and the normative ideals that underlie them have therefore been politicized and distorted, and instead of fulfilling principles of cultural equality and democratic inclusion, current arrangements rather aim at accommodating difference without disturbing the status quo.

In chapter 5, Geoffrey Brahm Levey shows that Australian multiculturalism has a distinctive architecture. He argues that Australian state multiculturalism is best understood as an expression of a broader "liberal nationalist" approach to national identity, citizenship, and cultural diversity that emerged as part of a reassessment of Australian identity. He sees three animating propositions in Australian multiculturalism as it relates to this question of national identity. Firstly, Anglo-Australian identity and culture were formative in establishing Australia's institutions and "way of life," and should be duly acknowledged. Secondly, national identity will inevitably change over time with the changing composition of Australian society. Thirdly, it must be ensured that all Australians, including those not of the majority culture, enjoy the same rights and opportunities. Levey concludes that Australian multiculturalism is a policy framework that seeks to check the culturalnationalist aspects of the core culture from overreaching and violating its liberaldemocratic aspects. This feature of Australian multiculturalism is not well grasped by the political class or the general public, and therefore those who cite Australia 
as further evidence of a worldwide trend toward liberal universalism, or a purely civic conception of the nation, fundamentally misread the Australian case.

In chapter 6, Katherine Smits shows that New Zealand is both bicultural and multicultural. The term "multiculturalism" was first introduced in New Zealand in the 1970 s to refer to settler-Maori relations, but it is now assumed to apply to the diversity resulting from non-British immigration. She argues that cultural pluralism in New Zealand is shaped by the interactions between shifting and competing discourses regarding multi- and biculturalism, indigenous peoples and civic values. New Zealand's national identity historically contains a strong commitment to social justice, but this was challenged by the neoliberalism of the mid-1980s. The related "rebranding" of New Zealand was aimed partly at encouraging foreign investment, but it also attempted to co-opt Maori communal values to mitigate the internal effects of welfare cuts. Public resistance was articulated through liberal nationalism cast in social justice terms, and by the Maori, who made calls for selfgovernment under the Treaty of Waitangi and emerging international norms. New Zealand's multiculturalism is therefore framed by the values and discourses of the various political, economic, and nationalist projects of state and nonstate actors. Yet it is also developed and invoked in order to support them, becoming a form of governmentality sustained by languages of value.

\section{PART III: THE “NEW" COMMONWEALTH}

In chapter 7, Rochana Bajpai details the "multicultural" elements in the Indian Constitution of 1950 that predate similar policies in Western democracies. These have given rise to an extensive regime of group rights that ranges across many policy areas and levels of government. Bajpai puts forward three key theses regarding the constitutional settlement and Indian multiculturalism more broadly. Firstly, rejection of colonial forms of devolved governance and the convergence of the interests of liberals and nationalists during constitution-making led to the emergence of a multicultural framework that was significantly "limited" in several respects. Secondly, India's constitutional compromise on multiculturalism suffers from a deficit in terms of normative justification, eliding the distinction between rights for members of groups, and rights for groups. Thirdly, although there has been a gradual expansion of multicultural policies, because of the normative deficit these are seen as discretionary concessions motivated by electoral considerations rather than matters of justice, which in turn plays into the rhetorical strategies of the Hindu Right. Bajpai concludes that multiculturalism in India therefore needs to recover resources from a range of alternative traditions to justify multiculturalism, and to complement the recent discursive shift back toward communitarian secularism, group rights, fair equality of opportunity, and more radical participatory democracy.

In chapter 8, Farah Godrej analyzes what appears to be an ambivalence about the notion of secularism in Gandhi's thought, which she argues is due to two different 
conceptions of religion. The first sees religion as a practice-based seeking after truth through reflection on one's own conscience, in the light of one's own religious traditions. This view relies on the Jainist metaphysic of anekantavada, which sees divine truth as something that can only ever be partially understood by a human mind situated in particular circumstances. The second view understands religion as claiming absolute doctrinal truth, which is the view of religion implicit in the metaphysics of the Abrahamic religions and at work in colonial missionary practices. Godrej argues that Gandhi thought the first "private" understanding of religion could nevertheless usefully inform a public political practice of engagement with other views, but that the second form of religion should be strictly separated from politics because of its tendency to facilitate competition and ideological entrenchment. This reconstruction of Gandhi's views shows him to have been prophetic regarding the debates around religion and secularism in modern India, which are arguably driven by a Western understanding of secularism that is anathema in the Indian context historically, politically, and on a deeper metaphysical level.

In chapter 9, Wale Adebanwi traces the history of cultural diversity in Nigeria, showing how it is intimately connected to colonial forms of rule and the influence of these on constitutional negotiations around independence. He argues that the federalism adopted at independence based on the existing administrative regions was problematic, since it institutionalized an unstable tripartite balance of power, encouraging the regions to become loci of loyalty competing with the nation itself, while simultaneously glossing over the existence of more than three hundred underlying minority groups. This led to civil war and (eventually) a more radical but more stable form of devolved government that better reflects Nigeria's vast diversity. Adebanwi concludes that the compromised form of federalism adopted at independence was largely the result of British practices of rule that constructed, not just the country itself, but also the problematic discourses through which the indigenous groups understood one another. This created an overall understanding of multiculturalism as a "menace," as well as a broader suspicion of polycentric government. This narrative is symptomatic of broader issues in postcolonial Africa, where failure adequately to manage multicultural difference has frequently led to overt or covert centralization, dictatorship, and the silencing of minorities.

In chapter 10, Daniel Goh examines the twin cases of Malaysia and Singapore. Against conventional explanations privileging nationalism, Goh argues that the key influence in each was state-building related to capitalist development, which responded to the contradictions of colonial and postcolonial racial formation. Given the racialized character of the division of labor inherited from Britain, each side pushed for a political multiracialism that suited its economic approach. This meant the state builders eventually fell out, because Singapore looked toward transforming itself into an industrial hub, while Kuala Lumpur privileged agrarian and natural resource capitalist development. Patronage multiracialism aligned with economic policy favoring the bumiputera ("son of the soil" in the Malay 
language) was institutionalized in Malaysia, whereas corporatist multiracialism abetting statist capital accumulation was pursued in Singapore. Goh argues that by the 1980 os and 1990 s the contradictions of postcolonial racial formation were surfacing in both states, which led to the adoption of new forms of multiculturalism supposedly more suited to an era of globalization. In the era of global financial crises, however, the old multiracialisms remain institutionally dominant over the new forms of multiculturalism. Goh concludes that although Malaysia and Singapore developed their political institutions and economies divergently and on different multiracial premises, the evolution of their forms of multiculturalism have been "arrested" by underlying political and economic contradictions.

In chapter 11, Viranjini Munasinghe examines the case of Trinidad and Tobago, concentrating on the approach to cultural diversity on the politically dominant, and more populous and diverse, island of Trinidad. ${ }^{28}$ She argues that the absence of a clear symbolic core to the nation-whether homogeneous settler, or indigenous-shapes Trinidadian multiculturalism. This multiculturalism is marked by a struggle where ethnic groups battle for the nation against the background of a rigid colonial racial hierarchy of Europeans as masters, Africans as slaves, and East Indians as indentured laborers. The legacy of this colonial racialization, combined with national imperatives to indigenize and mediate diversity, subsequently fixed African ancestry as the ideological culture-history referent. This made Afro-Creoles the legitimate inheritors of both nation and state, a cultural hegemony that, ironically, draws sustenance from homogenizing national narratives that invest only some groups with "native" privilege. Munasinghe concludes that more recent Indo-Trinidadian charges of state bias in sponsorship of Afro-Trinidadian culture have been possible only because homogenizing national narratives of creolization did not (or could not) establish an uncontestable new purity. In Trinidad, the dialectical play between homogenizing and cosmopolitan narratives and metaphors, founded on colonial race hierarchies, continues to resist consolidation of either African or Indian ancestry as the nation's symbolic core.

\section{CONCLUSIONS}

Multiculturalism is comprised of a series of overlapping issues and discourses, with the precise nature of what is at stake varying from country to country. This fluidity makes identifying common themes and questions difficult. As editors, we therefore decided to let the authors speak for themselves before drawing the different threads together in a concluding chapter. There we provide a philosophically inflected comparison of the different historical examples of multiculturalism that accounts for the variety across the Commonwealth, yet also draws out the deeper connections between its different forms. We argue that the dominant forms of multiculturalism in theory and practice are unduly narrow, leading to an unhelpful siloing of "multicultural" issues, groups, and rights. Ultimately, we conclude 
that achieving a fruitful, holistic multiculturalism requires modes of governance that are far more polycentric and pluralist than present ones.

"Multiculturalism" as we have narrated it here is part of the wider story of the development of the modern state through liberal-democratic governance, domestic nation- and state-building, and the rise and fall of imperialism. Britain is of course central to this story. As the leading imperial power, the first country to industrialize, and the progenitor of much modern liberal theory and practice, Britain has had a unique role - for good or ill-in forming the modern world. This role has helped to forge indelible connections between otherwise radically different countries, and the collapse of the British Empire after 1945 prompted a fundamental remaking of those nations and states. The postwar British Commonwealth is therefore vital for understanding the evolution of modern multiculturalism, and the dilemmas it poses for the theory and practice of contemporary liberal democracy.

\section{NOTES}

1. For another discussion of the scope of multiculturalism, see Jacob T. Levy, The Multiculturalism of Fear (Oxford: Oxford University Press, 2000), chap. 5. We share his view that in such accounts "[u]sefulness, not truth, is the goal" (p. 125). Imposing a rigid typology of multicultural groups of rights is unhelpful.

2. For a differing account of the relationship between the theory and practice of multiculturalism, see Will Kymlicka, "The Essentialist Critique of Multiculturalism: Theories, Policies, Ethos," in Varun Uberoi and Tariq Modood, eds., Multiculturalism Rethought: Interpretations, Dilemmas, New Directions (Edinburgh: Edinburgh University Press, 2015), 209-49. Kymlicka’s organizing vocabulary in "The Essentialist Critique" is different from ours, revolving around the distinction between philosophical approaches, actual policies, and real-world outcomes. By multicultural "policy," he means government responses to the full range of issues/groups covered by the political theory of multiculturalism. By "practice," he generally means the social outcomes of those policies, although he alleges his critics blur the distinction between the results of government policies and the philosophical justifications behind them (ibid., 225-29). In contrast, we use "policy" or "political practice" to mean government attempts to integrate minority immigrants, and the accompanying public debates. We distinguish multicultural policy/practice in this sense from the broader scope of the term "multiculturalism" in political theory. Nevertheless, our commitment to philosophical holism means that at some points we use "practice" as a more general contrast to "theory" in order to distinguish theoretical "webs of belief" from the social practices in which they are instantiated. Some of Kymlicka's arguments in "The Essentialist Critique" against the thinkers he calls "post-multiculturalist" turn on something like this broader distinction, although we believe our defense of polycentricity is not caught by these. In any event, the different uses of the terms are either specified or (we hope) clear from the context.

3. There is a clear historical correlation between the rise of liberal democracy and the development of the modern nation-state, and long-standing theoretical connections traceable to, inter alia, J.S. Mill (see "Of Nationality as Connected with Representative Government" in Mill, Considerations on Representative Government [London: Parker, Son, \& Bourn, 1861]). Many scholars have subsequently argued that some version of the cultural nation plays a key role in the functioning of modern governance, e.g., Benedict Anderson, Ernest Gellner, and David Miller.

4. See Richard T. Ashcroft and Mark Bevir, "Liberal Democracy, Nationalism and Culture: Multiculturalism and Scottish Independence," Critical Review of International Social and Political Philosophy 
21, no. 1 (2018): 65-86; Richard Ashcroft and Mark Bevir, "Pluralism, National Identity and Citizenship: Britain after Brexit," Political Quarterly 87 (2016): 355-59; and Mark Bevir, The Logic of the History of Ideas (Cambridge: Cambridge University Press, 1999).

5. See Mark Bevir, A Theory of Governance (Berkeley: University of California Press, 2013).

6. For instance, holism suggests that the application of existing theoretical frameworks is necessary for ordering and analyzing historical data, even if these frameworks must remain open to revision in the light of new information. Nevertheless, while we know that theory and practice continually remake each other, the ways in which they do so are not always apparent. Historical investigation may help to foreground these processes, thereby illuminating the dilemmas that have spurred reconstitution of beliefs, the traditions those beliefs draw on, and the practices through which they are expressed. Philosophical analysis of the normative issues raised by practical examples may thereby highlight overlooked similarities between different concrete cases, suggesting a change in how we approach these in practice. Inversely, a comparative historical examination may help to clarify the normative issues at stake, thereby problematizing existing philosophical frameworks and pointing to the value of a new set of philosophical questions and political arrangements.

7. These claims can be regarding the results of specific polices, laws, and discourses, or the broader social consequences of cultural diversity. We therefore agree with Kymlicka that clear evidence of the effects of multicultural policies in liberal democracies is "not easy to locate", and is both "tentative" and "preliminary" (Kymlicka, "Essentialist Critique," 216-17). It is notable, however, that Kymlicka attempts to assess the effects of multiculturalism on substate national minorities, indigenous peoples, and immigrant groups separately. We argue that this sort of typological separation of multicultural groups and rights is unstable philosophically and ineffective in political practice, which indicates that assessment of the real-world effects of multiculturalism should also be holistic, requiring both historical and philosophical investigation.

8. The influence of practice on theory can be seen in Kymlicka's later work (e.g., Multicultural Odysseys: Navigating the New International Politics of Diversity [Oxford: Oxford University Press, 2007], and "Essentialist Critique"), which is more empirical and comparative than his earlier more philosophical work (see his Liberalism, Community, and Culture [Oxford: Oxford University Press, 1989], and Multicultural Citizenship: A Liberal Theory of Minority Rights [Oxford: Oxford University Press, 1995]).

9. For a series of "histories" of the multicultural debate see "Introduction" and "Part I: Trajectories" of Anthony Simon Laden and David Owen, eds., Multiculturalism and Political Theory (Cambridge: Cambridge University Press, 2007). These histories emphasize different aspects of the debates, but are broadly compatible with each other and our account. While the connection to decolonization is widely acknowledged, we differ by foregrounding the ways in which the intersection of liberal, colonial, and multicultural governance conditioned the various forms of postwar multiculturalism, and in our suggested response of polycentricity and pluralism.

10. See Christian Joppke, "The Retreat of Multiculturalism in the Liberal State: Theory and Policy," British Journal of Sociology 55 (2004): 237-57.

11. Benedict Anderson, Ernest Gellner, Michel Foucault, Karl Polanyi, and Max Weber, all argue for this in their different ways.

12. See Historicism and the Human Sciences in Victorian Britain, ed. Mark Bevir (Cambridge: Cambridge University Press, 2017).

13. For convenience we use "United Kingdom" and "Britain" interchangeably, i.e., including Northern Ireland in both. We use "Old" and "New" Commonwealth to distinguish the white-settler colonies of Canada, Australia, and New Zealand from other colonies in the Empire that were never intended to be permanently settled by the British, and whose relationship to Great Britain was marked by more nakedly extractive practices. These terms have functioned historically as thinly veiled proxies for race, and their use is more common in Britain than elsewhere, but even though this volume problematizes them, we find the distinction helpful as shorthand. For the reasons given in $n .27$ below, we do not generally include South Africa and Zimbabwe in the Old Commonwealth. 
14. Different theorists conceptualize the debates according to their particular concerns, but many of these accounts are complementary rather than competing. For instance, multiculturalism is both a debate within liberalism between strands of universalism and contextualism, and a debate between liberalism and its communitarian, republican, and postcolonial critics. Multiculturalism is often associated with the identarian "politics of difference," yet this can be cast in terms of both "positional" and "cultural" difference, as it is by Iris Marion Young (see her "Structural Injustice and the Politics of Difference," in Laden and Owen, eds., Multiculturalism and Political Theory, 60-88). Nevertheless, it seems generally accepted that the early association of multicultural political theory with the claims of minority groups that were not overtly cultural (e.g., women or those with disabilities) later shifted to a focus on issues relating to immigrants and national minorities. The "politics of difference" is closely related to the "politics of recognition," which is broken down by Charles Taylor into the "politics of equal dignity" and the "politics of difference" (Charles Taylor, "The Politics of Recognition," in Amy Gutmann, ed., Multiculturalism: Examining the Politics of Recognition [Princeton, NJ: Princeton University Press, 1994]). In turn, multiculturalism as the "politics of recognition" is often contrasted-albeit controversially - with the "politics of redistribution" more closely associated with liberal egalitarian and social democratic theory (see Nancy Fraser's "From Redistribution to Recognition? Dilemmas of Justice in a 'Post-Socialist' Age," New Left Review 1, no. 12, July-August 1995, and Brian Barry's Culture and Equality [Malden, MA: Polity Press, 2001]). Feminist theory arguably cuts across all of these debates, with different theorists falling on different sides of the various divides. For useful introductions to, and summaries of, the political theory literature along these lines see Laden and Owen, eds., Multiculturalism and Political Theory; Sarah Song, Justice, Gender and the Politics of Multiculturalism (Cambridge: Cambridge University Press, 2007); and Song, "Multiculturalism," in The Stanford Encyclopedia of Philosophy, ed. Edward N. Zalta, accessed November 19, 2018, https://plato.stanford.edu/archives/spr2017/ entries/multiculturalism.

15. See Kymlicka, Liberalism, Community, and Culture and Multicultural Citizenship.

16. See Laden and Owen, eds., Multiculturalism and Political Theory, 7. Prominent respondents to Kymlicka include Charles Taylor, Iris Marion Young, Susan Moller Okin, Brian Barry, Chandran Kukathas, Bhikhu Parekh, James Tully, Roger Scruton, Jacob T. Levy, Seyla Benhabib, Kwame Anthony Appiah, Jeremy Waldron, and Sarah Song.

17. See James Tully, Strange Multiplicity: Constitutionalism in the Age of Diversity (Cambridge: Cambridge University Press, 1995), and Glen Sean Coulthard, Red Skin, White Masks: Rejecting the Colonial Politics of Recognition (Minneapolis: University of Minnesota Press, 2014).

18. "Context-sensitive" covers a broad range of theoretical approaches, ranging from utilizing historical examples to illustrate abstract points to more radical approaches that use historical context to generate normativity itself. For a fuller discussion, see Jacob T. Levy, "Contextualism, Constitutionalism, and Modus Vivendi Approaches," in Owen and Laden, eds., Multiculturalism and Political Theory, 173-97. By "politically oriented" we mean approaches that prioritize actual political processes, in particular democratic deliberation, in determining outcomes. For a helpful discussion, see Anthony Simon Laden, "Negotiation, Deliberation, and the Claims of politics," in Owen and Laden, eds., Multiculturalism and Political Theory, 198-217. For a fuller account of the effect of the contextual turn on multicultural political theory, see Song "Multiculturalism," and for an example of work that is sensitive to both contextual and political strands without being conditioned by them, see her Justice, Gender and the Politics of Multiculturalism.

19. The separation of groups and rights is central to Kymlicka's theory of multiculturalism as set out in his early work, and his influence over liberal multiculturalism and the wider debate has ensured that his typology is ubiquitous in the literature. Some version of it also seems to be implicit in other defenses of multiculturalism, such as Charles Taylor's politics of recognition, which draws on Herderian accounts of culture and defends the right to cultural survival in perpetuity. Taylor's views on Quebec clearly suppose that minority national groups have rights to some form of self-government that immigrant groups do not: see the report he co-authored with Gérard Bouchard, Report of the Commission 
on Accommodation Practices Related to Cultural Difference (Quebec: Government of Quebec, 2008). Postcolonial theorists such as Tully and Coulthard, who are critical of mainstream multiculturalism in theory and practice, also nevertheless advocate self-rule for indigenous groups historically subject to colonization, albeit that this does not turn squarely on the role of culture. Admittedly, some actors in the debate do not fall neatly into the typology as we have articulated it. For example, Iris Marion Young is broadly sympathetic to a multicultural politics of difference, yet rejects the usual multiculturalist focus on ethno-religious groups and the distribution of rights, instead focusing her critique on underlying structures of social power and domination. Alternative accounts of freedom from domination draw on civic republicanism and thereby emphasize the quality of social and political relations within and across groups, opening spaces for accommodations based on culture, as well as some group selfgovernment that is not. Critics of Kymlicka such as Brian Barry, Susan Moller Okin, and Roger Scruton reject most "multicultural" rights on principle, including robust political autonomy for minority groups. Chandran Kukathas takes the opposite view, granting self-rule to any group or association that desires it, albeit not directly on the basis of culture (see Kukathas, The Liberal Archipelago: A Theory of Diversity and Freedom [Oxford: Oxford University Press, 2003]). The later Kymlicka does move away from a strict application of his typology towards a greater emphasis on international discourses and more context-sensitive forms of multiculturalism. We will discuss this shift in more detail in the concluding chapter to this volume, but for now it suffices to note that much of the later Kymlicka's work is comparative and empirical rather than political theory per se, and so the norm in theoretical accounts of multiculturalism is still to focus on immigrants, national minorities, and indigenous peoples as separate groups, and only seriously to contemplate substantive self-rule for the latter two.

20. Kymlicka's and Charles Taylor's multiculturalism has clear links to cultural nationalism (see notes 3 and 4 above), as do recent debates about "muscular liberalism" and national identity in the UK and elsewhere.

21. See Celeste Lipow MacLeod, Multiethnic Australia: Its History and its Future (Jefferson, NC: MacFarland, 2006); Alain G. Gagnon and Raffaele Iacovino, Federalism, Citizenship and Quebec: Debating Multinationalism (Toronto: University of Toronto Press, 2007); Alan C. Cairns, First Nations and the Canadian State: In Search of Coexistence (Kingston, Ont.: Institute of Intergovernmental Relations, Queen's University, 2005); Andrew Sharp, Justice and the Māori: Māori Claims in New Zealand Political Argument in the 1980s (Oxford: Oxford University Press, 1990); and Paul M. Sniderman and Louk Hagendoorn, When Ways of Life Collide: Multiculturalism and Its Discontents in the Netherlands (Princeton, NJ: Princeton University Press, 2009).

22. See Michael A. Burayidi, ed., Multiculturalism in a Cross-National Perspective (Lanham, MD: University Press of America, 1996); Fethi Mansouri, ed., Cultural, Religious and Political Contestations: The Multicultural Challenge (Cham, Zug, Switzerland: Springer, 2015); and Fethi Mansouri and Boulou Ébanda de B'béri, eds., Global Perspectives on the Politics of Multiculturalism in the 21st Century: A Case Study Analysis (London: Routledge, 2014).

23. See Ofra Bengio and Gabriel Ben-Dor, eds., Minorities and the State in the Arab World (Boulder, CO: Lynne Reiner, 1999); Maya Shatzmiller, ed., Nationalism and Minority Identities in Islamic Societies (Montreal and Kingston, Ont.: McGill-Queen's University Press 2005); Will Kymlicka and Baogang He, eds., Multiculturalism in Asia (Oxford: Oxford University Press, 2005); and Irene Bloemraad, Becoming a Citizen: Incorporating Immigrants and Refugees in the United States and Canada (Berkeley: University of California Press, 2006).

24. See James Crawford, The Rights of Peoples (Oxford: Clarendon Press, 1988); Samuel L. Myers and Bruce P. Corrie, eds., Racial and Ethnic Economic Inequality: An International Perspective (New York: Peter Lang, 2006); Paul Havemann, Indigenous Peoples' Rights in Australia, Canada \& New Zealand (Oxford: Oxford University Press, 1999); Keith Banting and Will Kymlicka, eds., Multiculturalism and the Welfare State: Recognition and Redistribution in Contemporary Democracies (Oxford: Oxford University Press, 2006); Will Kymlicka, Multicultural Odysseys (Oxford: Oxford University Press, 2007), Rachel Sieder, ed., Multiculturalism in Latin America: Indigenous Rights, Diversity and Democracy (New 
York: Palgrave Macmillan, 2002); and Christian Joppke, Immigration and the Nation State: The United States, Germany, and Great Britain (New York: Oxford University Press, 1999).

25. For the broader comparative work on policy, law, and governance, see e.g., Crawford Young, Ethnic Diversity and Public Policy: A Comparative Inquiry (New York: Macmillan, 1998); and Augie Fleras, The Politics of Multiculturalism: Multicultural Governance in Comparative Perspective (New York: Palgrave Macmillan, 2009). For a sample of the vast array of detailed work in the social sciences, see, e.g., Matthew Wright and Irene Bloemraad, "Is There a Trade-off between Multiculturalism and Socio-Political Integration? Policy Regimes and Immigrant Incorporation in Comparative Perspective," Perspectives on Politics 10, no. 1 (2012); John Sides and Jack Citrin, "European Opinion about Immigration: The Role of Identities, Interests and Information," British Journal of Political Science 37 (2007): 477-504; and Steven Weldon, "The Institutional Context of Tolerance for Ethnic Minorities: A Comparative, Multilevel Analysis of Western Europe," American Journal of Political Science 50, no. 2 (2006): 331-49.

26. Arguably Multiculturalism in Asia by Kymlicka and $\mathrm{He}$ is a work in a similar vein.

27. South Africa and Zimbabwe (formerly Rhodesia) can be considered part of the Old Commonwealth, and were by British elites in the first half of the twentieth century. We have not, however, considered them in this volume, for two main reasons. Firstly, their histories of institutionalized racial apartheid were not aimed at integrating immigrants or granting genuine self-rule to minorities, but rather attempts to control and oppress a majority racial "group." They are therefore part of the broader story of decolonization but do not sit easily within a discussion of genuine attempts at accommodating cultural (or other) diversity (see Kymlicka in Liberalism, Community, and Culture, chap. 13). Secondly, both of these countries left the Commonwealth in the 1960s, although they later rejoined (and in Zimbabwe's case, left again). Their forms of governance were therefore deeply isolationist for a long period of the twentieth century and had very little overlap with the policies of bi- and multiculturalism developed in Canada, Australia, and New Zealand.

28. Since it is almost entirely populated by people of African descent, the island of Tobago (which has a population of around 6o,ooo, compared to Trinidad's 1.3 million) is much less ethnically diverse than Trinidad, and political/economic power is therefore overwhelmingly Trinidadian, as are the dominant narratives of nationhood. We follow Viranjini Munasinghe in using "Trinidad," "Indo-Trinidadian," and "Afro-Trinidadian," common shorthand that makes sense especially in a discussion of multiculturalism. 
